\title{
INTERNATIONAL REACH OF SECURITIES REGULATION: A COMPARATIVE VIEW ON BRAZILIAN AND U.S. LAW
}

Gabriel Valente dos Reis

\begin{abstract}
Professor of Law at the Federal Rural Rio de Janeiro University (Universidade Federal Rural do Rio de Janeiro - UFRRJ). Ph.D. candidate in International Law at the University of São Paulo (USP) Law School. Ph.D. candidate in International Law at the State University of Rio de Janeiro (UERJ) Law School. Master of Laws (USP, summa cum laude). Attorney.
\end{abstract}

Abstract: This paper examines the international reach of securities regulation, focusing on the Brazilian and U.S. experiences in this field. The aim is to provide the reader with a view on how the issue first developed in the U.S. (and how the U.S. Supreme Court has recently changed, in part, the U.S. solution) and on how Brazilian Law, on its part, addresses regulation of transnational securities markets - mentioning particularly a landmark Administrative Enforcement Proceeding judged by the Brazilian regulatory authority (CVM).

Keywords: Securities regulation - Transnational markets - Brazil Conduct and effects test - CVM.

\section{INTRODUCTION}

The scope of this paper is to examine the international reach of securities regulation, in a comparative perspective between developments in the subject in the United States (U.S.) and Brazil.

In part 2, the challenges of regulating capital markets in a world characterized by increasingly interconnected markets are described. In part 3, the evolution of theories concerning the international reach of anti-fraud regulation in the United States is addressed. Part 4 focuses upon how the issue is treated under current Brazilian law, instead with a slightly different focus, on how the Comissão de Valores Mobiliários - CVM (Brazilian securities authority) has dealt with the problem of its international jurisdiction to investigate and punish frauds. In part 5, the importance of sound characterization is highlighted, and final remarks are made in part 6. 


\section{CAPITAL MARKETS REGULATION AND THE CHALLENGE OF TRANSNATIONALIZATION}

Regulation first appeared as a tool to correct market failures, so as to assure the adequate functioning of markets, protecting the interests of society. The need of public regulation in the capital markets became evident, in the U.S., after the 1929 New York stock exchange collapse and the Great Depression that followed in subsequent years ${ }^{1}$. From thereof, regulatory structures emerged in many countries.

In Brazil, however, such move occurred much later, with the enactment of Law $n^{\circ} 4.729 / 1965$ and, after more than one decade, of Law $^{\circ}{ }^{6} 6.385 / 1976$ (both still in force, though with some amendments). The latter created the Comissão de Valores Mobiliários (CVM), which has played a crucial role in the enactment of rules and enforcement in the Brazilian securities market.

Nonetheless, this system based on regulation by each National State of its own market faces big challenges nowadays. With the exponential transnationalization of markets seen in the last decades, cases simultaneously connected to different legal orders became common.

Much is due to technology, which eliminates the meaning of national borders for investors, adding to the fact that organized markets (and notably stock exchanges) have shifted into truly transnational entities through consolidation processes ${ }^{2}$.

One must notice that, notwithstanding regulatory disparities, market participants have took advantage from internationalization: many companies resort to different markets in order to finance their businesses, being listed in more than one financial center. Global diversification, moreover, reduces portfolio risk ${ }^{3}$.

Until not so long ago, U.S. securities markets were so much stronger than other markets that the U.S. were able to impose, to a large extent, through the Securities and Exchange Commission (SEC), its own rules and requirements to issuers and intermediaries of other countries, who resorted mainly to that market - yet, this is not the case anymore, within the context of a more diversified global economy ${ }^{4}$.

Eric C. Chaffee ${ }^{5}$ makes an interesting comparison: the current

1 See Rachel Sztajn, Regulação e o mercado de valores mobiliários, Revista de Direito Mercantil, vol. 53, n ${ }^{\circ} 135,2004$, p. 139.

2 Eric C. Chaffee, A moment of opportunity: reimagining international securities regulation in the shadow of financial crisis, Nexus: Chapman's Journal of Law \& Policy, n. 15, p. 29.

3 Onnig H Dombalagian. Choice of law and capital markets regulation, Tulane Law Review, n. 82, 2008, pp. 1920-1929.

4 Roberta S.Karmel; Claire R. Kelly, The hardening of soft law in securities regulation, Brooklin Journal of International Law, vol. 34, 2009, p. 886.

5 Eric C. Chaffee,op. cit., pp. 30-31. 
state of global capital markets issimilar to the situation of U.S. markets before the Securities Actof 1933, whose enactment was prompted by the 1929 crisis. Up to that moment, there were dozens of different regulatory structures in the U.S., one for each federal state. The Securities Actcame to set forth some important uniform standards.

According to the author, we now face the same challenge in the global sphere - a variety of national rules is used in trying to regulate securities markets that transcend national borders. In particular, the financial crisis which started in 2008 might be a catalyzer for the development of international securities regulation ${ }^{6}$. In such scenario, one needs to consider two opposing risks: sub-optimal regulation and overregulation ${ }^{7}$. An adequate balance must be reached, assuring reasonable regulation.

Notwithstanding the merits of truly international instruments, like treaties ${ }^{8}$ and soft law $w^{9}$, in the current stage attention must be given to the issue ofthe applicable national laws, inasmuch as, at least for the moment, domestic sources largely prevail in the field of securities regulation.

Moreover, many differences between regulatory systems might be legitimate consequences of identity or cultural differences ${ }^{10}$. Social and political aspects also influence corporate governance structures prevailing in a given society ${ }^{11}$, which impacts regulation, so that largescale uniformity is very unlikely in the short term.

Indeed, there is strong resistance against international uniformity, as Bebchuk and Roe point out when addressing the convergence of corporate governance standards, building their "path dependence theory"12. The same argument can be made as to capital markets regulation.

Thus, once differences still prevail, delimitating the reach of each national regulatory system remains necessary. Andreas Lowenfeld

6 Eric C. Chaffee, op. cit., p. 34.

7 Herbert Kronke, Capital Markets and Conflicts of Laws, Recueil des Cours, vol. 286, 2000, p. 362 .

8 See, for example, the UNIDROIT Geneva Convention on Substantive Rules for Intermediated Securities of 2009.

9 Notice that many soft law rules were prepared by entities such as IOSCO (International Organization of Securities Commissions), OECD and IASB (International Accounting Standards Board).

10 Amir Lichtet al, Culture, law, and corporate governance, International Review of Law \& Economics, n. 25, 2005, , pp. 229-236.

11 See Mark Roe, Political Determinants of Corporate Governance. Oxford: Oxford University Press, 2003.

12 LucianBebchuk; Mark Roe, $A$ Theory of Path Dependence in Corporate Governance and Ownership, Working Paper $n^{\circ} 131$, Columbia Law School, The Center for Law and Economic Studies, 1999. 
observed already in 1979 that governments increasingly intervened in the economy, while more and more activities were developed beyond national borders. Adding to this the blurring of the classic division between public and private law; Professor Lowenfeld rightly concluded that public law, just like private, can and must be carefully assessed when traveling overseas ${ }^{13}$.

\section{INTERNATIONAL REACH OF SECURITIES REGULATION - THE U.S. APPROACH}

\subsection{The conduct and effects test}

In the U.S., the issue of the international reach of anti-fraud regulation issued by SEC in pursuance of10 (b) of the Securities Exchange Act of 1934 has been discussed for decades. After many judgments, the majority of U.S. courts came to adopt the conduct and effects test, developed by Judge Friendly at the Court of Appeals for the Second Circuit $^{14}$, located in the financial center of the country.

The conduct and effects test implies making the following questions: (i) has the conduct happened in the U.S. territory?; and (ii) has the conduct caused substantial effects in the U.S. territory or to U.S. citizens? The combined answers to both questions shall lead to a conclusion as to the reasonableness of applying or not U.S. regulation ${ }^{15}$. Such test is also provided for in Section 416 of the Restatement Third of Foreign Relations Law (1986).

\subsection{The U.S. Supreme Court Opinion in Morrison and the presumption against extraterritoriality}

More recently, the conduct and effects doctrine was abandoned (at least in part) in the case Morrison et al. v. National Australia Bank Ltd. et al (2010) ${ }^{16}$, in which the U.S. Supreme Court addressed the issue for the first time.

The defendant National Australia Bank Ltd. (NAB), an Australian bank whose ordinary shares were not traded in any U.S. stock exchange (there were, however, American Depositary Receipts

13 Id., pp. 326-329.

14 See Schoenbaum v. Firstbrook (1968); Leasco Data Processing Equip. Corp. v. Maxwell (1972); Bersch v. Drexel Firestone, Inc.(1975); IIT v. VencapLtd. (1975); e IIT v. Cornfeld (1980).

15 In ItobaLtd. v. LepGroup PLC (1995), it became clear that a combination of both tests was the best way to proceed.

16 U.S. Supreme Court, Morrison et al v. National Australia Bank Ltd. et al., Certiorari to the United States Court of Appeals for the Second Circuit, 24.06.2010. 
International Reach of Securities Regulation - Gabriel Valente dos Reis of the bank negotiated in the New York Stock Exchange) had acquired co-defendant Home Side Lending, a company headquartered in Florida, U.S., with activities in the mortgage business.

The acquisition resulted in big losses and plaintiffs, who had bought $N A B$ securities before the write-off of such losses, decided to sue the two companies and their managers for alleged manipulation of financial models, which would have led, according to them, to an undue overvaluation of Home Side Lending.

In Morrison, the U.S. Supreme Court abandoned the traditional conduct and effects test, opting instead to adopt the theory of presumption against extraterritoriality to interpret statutes. Arguing that the traditional tests were complex and unpredictable, the Court took the view that Section 10 (b), in the absence of express mention to extraterritorial application, was applicable only to (i) transactions involving securities listed in the U.S.; or (ii) transactions concluded in the U.S. involving other securities ${ }^{17}$.

The other line of argument made by plaintiffs was also rejected: plaintiffs had argued that, in reality, there was no extraterritoriality issue at all, for the illegal conducts (financial manipulation and illegal declarations) had occurred in Florida. Instead, the Supreme Court was of the view that the relevant factor was where the transaction of securities took place - and not the place of origin of the purported fraud ${ }^{18}$.

\subsection{The Dissenting Opinion and the Congress reaction}

In Morrison, there was a strong Dissenting Opinion by Justice Stevens, who was joined by Justice Ginsburg. Notwithstanding the fact that such judges concurred with the final result, i.e., the non-applicability of U.S. law to the case ${ }^{19}$, they entirely disagreed with the justification given by the majority.

The Justices noted that U.S. courts had been interpreting Section 10 (b) in a way totally different from the view of the Morrison majority. For about four decades, the inferior courts had been resorting to the test of conduct and effects developed by the Second Circuit and adopted in Section 416 of the Restatement Third - and never had the Congress or $\mathrm{SEC}$, during all this time, raised against the rule.

The dissenting Justices noticed that the Second Circuit had been refining its test for decades, judging dozens of cases and benefitting from the concurrence of other Circuits and the acquiescence of

17 Morrison et al v. National Australia Bank Ltd. et al., Opinion of the Court, pp. 11-16.

18 Morrison et al v. National Australia Bank Ltd. et al., Opinion of the Court, p. 17 e p. 24.

19 The reason for concurring with the final result was that share holders were not sucessful in proving that the "heart" of the frau took place in the U.S. or that there were detrimental effects to U.S. investorsor U.S. markets. Cf. Morrison et al v. National Australia Bank Ltd. et al., J. Stevens, p. 13. 
Congress and SEC. Therefore, there was no usurpation of Congress powers involved in the test, inasmuch as Congress itself left margin for judicial discretion ${ }^{20}$. In the dissidence view, the Supreme Court was simply ignoring the wisdom and experience accumulated for decades by inferior courts ${ }^{21}$.

In any case, they posited that the presumption against extraterritoriality is not a clear rule, but instead a flexible one, nor is it incompatible with the conduct and effects test - the real issue is the sufficient contacts needed for the incidence of Section 10(b), there being no easy answer to this problem ${ }^{22}$.

The Dissenting Opinion remarked that, in its interpretation, the new rule then established by the Supreme Court affected only private rights of action, and not in any manner whatsoever actions intended by $\mathrm{SEC}^{23}$.

Notice that shortly after the Morrison judgment, the U.S. Congress passed, in response to the 2008 financial crisis, the DoddFrank Wall Street Reform and Consumer Protection Act (published in July, 21 ${ }^{\text {st }}$, 2010), which expressly stated in Section 929P that, in the case of actions brought by SEC or by the Federal Government, the conduct and effects test shall apply. In such actions specifically, given the position taken by the Congress, there should be no more room for applying the presumption against territoriality, at least in the version envisaged by the Morrison Court ${ }^{24}$.

\section{THE CURRENT STATE OF BRAZILIAN LAW - THE CVM'S INTERNATIONAL JURISDICTION}

Notice that, as already mentioned, Brazilian securities regulation is much younger that U.S.'s. With this in mind, taking inspiration from the U.S. experience, the conduct and effects test was adopted in Brazil specifically to define the international reach of CVM's administrative jurisdiction to investigate and punish fraudulent conducts in the market. This was made through Presidential Decree n. 3.995/2001, which added $\S 6^{\circ}$ to Article $9^{\text {th }}$ of Law n. $6.385 / 1976$ :

" $\$ 6^{\circ}$ The Commission shall be competent to investigate and punish fraudulent conducts in the securities market whenever: I - its effects cause

20 Morrison et al v. National Australia Bank Ltd. et al., J. Stevens, pp. 1-5.

21 Morrison et al v. National Australia Bank Ltd. et al., J. Stevens, p. 14.

22 Morrison et al v. National Australia Bank Ltd. et al., J. Stevens, pp. 7-9.

23 Morrison et al v. NationalAustralia Bank Ltd. et al., J. Stevens, p. 11, esp. footnote n. 12.

24 As to possible different views on the issue, see Linda J. Silberman, Morrison v. National Australia Bank: implications for global securities class actions, Yearkbookof Private International Law, vol. 12, 2010, p. 126. 
damages to persons resident in the national territory, without regard to the place where they occurred; and II - the relevant acts or omissions took place within the national territory. "25

There is uncertainty regarding such provision, for a Presidential Decree, due to the separation of powers principle, was not the proper means of amending a statute enacted by Congress. Accordingly, the Decree's unconstitutionality is being argued in an lawsuit brought by the Federal Council of the Brazilian Bar (Conselho Federal da Ordem dos Advogados do Brasil) before the Supreme Court (Supremo Tribunal Federal - STF) - ADI n. 2601-1/600 - DF, which is still waiting for decision.

However, even if the STF considers in the future the Decree unconstitutional, we believe that the conduct and effects test can well keep being applied in the field of securities (be it with regard to administrative jurisdiction or to applicability of the law), for analogy reasons, for Brazilian Antitrust Law expressly provides for the test in Article $2^{\text {nd }}$ of Law n. 12.529/201126.

"Art. $2^{\text {nd }}$. This Law shall apply, without prejudice to conventions and treaties to which Brazil is a signatory, to practices wholly or partly undertaken in the national territory or which produce or might produce effects in it".

Comparative Law (especially U.S. Law, as seen above) should also help to justify the resort to the test of conduct and effects in Brazil, even if $\S 6$ of Article $9^{\text {th }}$ of Law n. 6.385/1976 comes to be deemed unconstitutional and, as a result, is invalidated by judicial review. Of course, a new legislative provision should be enacted (addressing not only administrative jurisdiction, but also applicable law), in order to provide market agents and authorities more legal certainty.

It is noteworthy that jurisdiction and applicable law are entirely autonomous matters in the International Conflict of Laws theory. Nonetheless, in the field of Brazilian securities regulation enforcement,

25 Non-official translation by this author. Original: " $\S 6^{\circ} \mathrm{A}$ Comissão será competente para apurar e punir condutas fraudulentas no mercado de valores mobiliários sempre que: I- seus efeitos ocasionem danos a pessoas residentes no território nacional, independentemente do local em que tenham ocorrido; e II - os atos ou omissões relevantes tenham sido praticados em território nacional."

26 Non-official translation by this author. Original: “Art. 2. Aplica-se esta Lei, sem prejuizo de convenções e tratados de que seja signatário o Brasil, às práticas cometidas no todo ou em parte no território nacional ou que nele produzam ou possam produzir efeitos." 
there are cases where these 1ssues are closely linked, as we shall see below.

In the Administrative Enforcement Proceeding n. SP2007/011727, ruled in February, 26 2008 (Processo Administrativo Sancionador $P A S$ ), the CVM Board (Colegiado da CVM) condemned the defendant to an administrative penalty of impediment to be manager or member of the Fiscal Council of publicly-held companies (companhias abertas), for 5 (five) years, due to insider trading.

The accused was a member of the Board of Directors of Sadia $S / A$ (a Brazilian large food company) who traded ADRs of its competitor Perdigão $S / A$ (which was about to receive an take over bid from Sadia) in the New York Stock Exchange.

CVM's Reporting Administrative Judge (Diretor-Relator) Eli Loria, noticing that "extraterritoriality is not something alien to national law, being provided for in Articles $7^{\text {th }}$ of the Criminal Code and Article $7^{\text {th }}$ of the Military Criminal Code", concluded that the text of the above mentioned Article $9^{\text {th }}, \S 6$, of Law n. 6.385/76 leaves no doubts as to CVM's jurisdiction to investigate the conduct at stake.

Loria mentioned also Article 10 of Law n. 6.385/76 28 , which provides for international cooperation to investigate "violations of rules concerning the securities markets which occurred within the country or overseas".

Another Administrative Judge, Marcos Barbosa Pinto, stressed that the notion of "fraudulent conduct" of Article $9^{\text {th }}, \S 6$, of Law n. $6.385 / 76$ shall be interpreted as any fraud in the general meaning, not being restricted to those fraudulent transactions provided for in CVM Instruction n. 08/1979.

However, Barbosa Pinto accepted the defense's argument that the violation of the duty of loyalty (dever de lealdade) for which the accused was being charged should not be considered, in the technical meaning, a fraud for purposes of $\S 6$.

But Barbosa Pinto was of the view that CVM's jurisdiction set forth in $\S 6$ was not exhaustive, so that the Brazilian authority was allowed to act in other occasions, such as in the presence of violation of the Brazilian Corporations Law (Lei das Sociedades por Ações - Law n. 6.404/1976), as provided for in Article 11 of Law n. 6.385/1976 ${ }^{29}$.

27 Available at: http://www.cvm.gov.br/port/inqueritos/2008/rordinario/inqueritos/02_26 SP2007-0117.asp, accessed on 15.10.2013.

28 “Art. 10. A Comissão de Valores Mobiliários poderá celebrar convênios com órgãos similares de outros países, ou com entidades internacionais, para assistência e cooperação na condução de investigações para apurar transgressões às normas atinentes ao mercado de valores mobiliários ocorridas no País e no exterior."

29 “Art . 11. A Comissão de Valores Mobiliários poderá impor aos infratores das normas desta Lei, da lei de sociedades por ações, das suas resoluções, bem como de outras normas legais cujo cumprimento lhe incumba fiscalizar, as seguintes penalidades: [...]" 
Considering that Sadia S.A. Was a company 1ncorporated in accordance with Brazilian Law and that it had its headquarters in the Brazilian territory, the Brazilian Corporations Law was applicable in pursuance of Article 60 of Decree-Law n. 2.627/1940 ${ }^{30}$ and Article 11 of Decree-Law n. 4.657/1942 (Introductory Law to the Brazilian Rules - Lei de Introdução às Normas do Direito Brasileiro) ${ }^{31}$.

Barbosa Pinto remarked that this was no confusion between international jurisdiction and applicable law issues, "but, on the contrary, it was a case where the reach of jurisdiction is given by the applicability of the law". Indeed, the competence set forth in Article 11 of Law n. $6.385 / 1976$ is a direct consequence of the Brazilian Corporations Law applicability.

Administrative Judge Sergio Weguelin agreed with the punishment imposed and with the final remarks made by Barbosa Pinto, adding yet another line of argument:

"the relationship between manager and corporation, both Brazilians, took place in Brazil, with the features and duties provided for in the country's legislation. Therefore, I understand that the duty of loyalty, as set forth in art. 155 of Law n. 6.404/76, was 'located' in Brazil. And its violation, consequently, also occurred in Brazil, though through a transaction overseas. In other words, in my view, the place of negotiation is not a determinant. The purchase could have occurred anywhere. Or otherwise there could be another way of violating the duty of loyalty, not necessarily through a purchase of securities "32.

30 “Art. 60. São nacionais as sociedades organizadas na conformidade da lei brasileira e que têm no país a sede de sua administração. Parágrafo único. Quando a lei exigir que todos os acionistas ou certo número deles sejam brasileiros, as ações da companhia ou sociedade anônima revestirão a forma nominativa. Na sede da sociedade ficará arquivada uma cópia autêntica do documento comprobatório da nacionalidade."

31 "Art. 11. As organizações destinadas a fins de interesse coletivo, como as sociedades e as fundações, obedecem à lei do Estado em que se constituírem. $\S 1^{\circ}$ Não poderão, entretanto ter no Brasil filiais, agências ou estabelecimentos antes de serem os atos constitutivos aprovados pelo Governo brasileiro, ficando sujeitas à lei brasileira. $\$ 2^{\circ}$ Os Governos estrangeiros, bem como as organizações de qualquer natureza, que eles tenham constituído, dirijam ou hajam investido de funções públicas, não poderão adquirir no Brasil bens imóveis ou susceptíveis de desapropriação. $\S 3^{\circ}$ Os Governos estrangeiros podem adquirir a propriedade dos prédios necessários à sede dos representantes diplomáticos ou dos agentes consulares."

32 Non-official translation by the author of this paper. Original: "o relacionamento entre $o$ administrador e a companhia, ambos brasileiros, desenvolvia-se no Brasil, revestido pelos atributos e deveres previstos na legislação do país. Assim, entendo que o dever de lealdade, conforme estabelecido no art. 155 da Lei 6.404/74, 'estava' no Brasil. E sua quebra, portanto, também ocorreu no Brasil, ainda que por meio de uma operação no exterior. Em outras 
The other two Administrative Judges (Durval Soledade and

Maria Helena Santana) concurred with the opinion of the Reporting Judge, however with the reservations made by Barbosa Pinto and Weguelin.

\section{THE IMPORTANCE OF SOUND CHARACTERIZATION}

Transnational capital markets are very complex: the same conduct might be subject to rules of private law, administrative regulation, self-regulation, criminal law etc in different countries.

This situation makes the issue of characterization a crucial one in order to define the law applicable to the case. Characterization (qualificação) is a traditional subject of International Conflict of Laws theory. When facing cross-border cases, one needs to previously characterize the matter at stake, so that the proper choice of law rule can be found and applied, thus leading to a given legal order whose substantive rules shall resolve the case ${ }^{33}$.

Therefore, while corporate issues shall be resolved by the lex societatis (law applicable to legal persons), regulation of frauds in securities markets follows different standards - as we have seen, the test of conducts and effects has been an important technique to define the international reach of public regulation in this sphere.

The dissent among Brazilian CVM Administrative Judges concerning the characterization of insider trading in PAS n. SP2007/0117 as something related to fraudulent conduct or otherwise as a violation of the corporate duty of loyalty, and the diverse connection factors depending on the chosen characterization (conduct and effects test in the former case; lex societatis in the latter), testify to the importance of sound characterization when dealing with transnational securities markets.

\section{FINAL REMARKS}

The unprecedented transnationalization of markets which took place during the last decades is a big challenge for legal thought, there being need to avoid two opposing risks: sub-optimal regulation and overregulation. In this context, the issue of international reach of national regulations is crucial, notwithstanding the usefulness of truly international instruments such as treaties and soft law.

palavras, no meu entender, o ambiente de negociação não é determinante. A compra poderia ocorrer em qualquer lugar. Ou, ainda, poderia ser uma hipótese em que o dever de lealdade fosse descumprido por um outro modo, que não a compra de um valor mobiliário".

33 See Gabriel Valente dos Reis, O Direito Internacional Privado e a teoria das qualificações: uma revisão do método conflitual a partir do princípio da proximidade, Revista de Direito do Estado, n. 13, 2009, pp. 293-325. 
In the U.S., the conduct and effects test was developed to define the reach of U.S. anti-fraud rules. The test was abandoned in part by the Supreme Court in Morrison (2010), specifically when addressing private rights of action - in such case, the Morrison Court preferred instead to apply the so-called presumption against extraterritoriality. However, the U.S. Congress made it clear, through the approval of the Dodd-Frank Act, that the conduct and effects test is still pertinent in actions intended by SEC or by the Federal Government.

In Brazil, the conduct and effects test is set forth as criteria do define the international jurisdiction of CVM to investigate and punish frauds, as provided for in Article $9^{\text {th }}, \S 6$, of Law n. 6.385/1976, as amended by Decree n. 3.995/2001, being the constitutionality of this decree currently object of a lawsuit in the STF (Brazilian Supreme Court).

In PAS n ${ }^{\circ}$ SP2007/0117 proceedings, the CVM Board punished a Brazilian insider who had traded ADRs of Perdigão $S / A$ in the New York Exchange. The Reporting Administrative Judge made use of the conduct and effects test to attest CVM's jurisdiction in the case, while the remaining Administrative Judges deemed the issue to be a corporate law one, noticing the jurisdiction of CVM to investigate and punish violations of Brazil's Corporations Law (applicable in the case as the lex societatis), as set forth by Article 11 of Law n. 6.385/76. The proper characterization was an important issue.

At the end of his course at The Hague Academy of International Law, Herbert Kronke pointed to the need of improvement in the communication channels between international lawyers and capital markets lawyers, for the fast internationalization of markets increases the need of linking both fields of knowledge - accordingly, no one should try to "invent the wheel" 34 .

This paper amounts to an effort of dialogue between Private International Law and Capital Markets Law, focusing particularly on the Brazilian and U.S. experiences, being aware that the healthy development of the global economy is increasingly dependent on improvements in regulation of transnational securities markets.

\section{REFERENCES}

BEBCHUK, Lucian; ROE, Mark.A Theory of Path Dependence in Corporate Governance and Ownership, Working Paper n. 131, Columbia Law School, The Center for Law and Economic Studies, 1999.

CHAFFEE, Eric C. A moment of opportunity: reimagining international securities regulation in the shadow of financial crisis, Nexus: Chapman's

34 Herbert Kronke,Capital Markets and Conflicts of Laws, Recueil des Cours, vol. 286, 2000, p. 380 . 
Journal of Law \& Policy, n. 15.

DOMBALAGIAN, Onnig $\mathrm{H}$. Choice of law and capital markets regulation, Tulane Law Review, n. 82, 2008.

KARMEL, Roberta S.; KELLY, Claire R.The hardening of soft law in securities regulation, Brooklyn Journal of International Law, vol. 34, 2009.

KRONKE, Herbert. Capital Markets and Conflicts of Laws, Recueil des Cours, vol. 286, 2000, p. 362.

LICHT, Amir, et al. Culture, law, and corporate governance, International Review of Law \& Economics, n. 25, 2005, pp. 229-236.

LOWENFELD, Andreas. Public law in the international arena: conflict of laws, international law, and some suggestions for their interaction, Recueil des Cours, v. 163, 1979.

ROE, Mark. Political Determinants of Corporate Governance. Oxford: Oxford University Press, 2003.

SILBERMAN, Linda J. Morrison v. National Australia Bank: implications for global securities class actions, Yearkbook of Private International Law, vol. 12, 2010.

SZTAJN, Rachel. Regulação e o mercado de valores mobiliários, Revista de Direito Mercantil, vol. 53, n. 135, 2004.

VALENTE DOS REIS, Gabriel. O Direito Internacional Privado e a teoria das qualificações: uma revisão do método conflitual a partir do princípio da proximidade, Revista de Direito do Estado, n. 13, 2009, pp. 293-325. 